\title{
Evaluation of Different Methods of Sowing of Sunflower at Farmers' Field in Central Plain Zone of Punjab, India
}

\author{
Bindu, Manoj Sharma*, Jatinder Manan and Gurmeet Singh \\ PAU's Krishi Vigyan Kendra, Kapurthala 144620 (Punjab), India \\ *Corresponding author
}

\begin{tabular}{|c|c|}
\hline \multicolumn{2}{|r|}{ A B S T R A C T } \\
\hline $\begin{array}{l}\text { Cost of production, } \\
\text { Gross profit, } \\
\text { Methods of sowing, } \\
\text { Sunflower. }\end{array}$ & \multirow{3}{*}{$\begin{array}{l}\text { This study was undertaken to evaluate the performance of sunflower sown } \\
\text { by different methods in comparison to the manual sowing. The yield } \\
\text { obtained in manual sown crop with the help of marker was found to be } \\
\text { higher as compared to mechanical planter. Maximum gross profit was } \\
\text { obtained under mechanical planting with thinning followed by manual } \\
\text { sown with marker, which was more suitable than mechanical planting with } \\
\text { thinning due to requirement of labour at the sowing time only. Hence, the } \\
\text { farmers were advised to go for manual planting with marker and } \\
\text { mechanical planting only if labour was available for the thinning. }\end{array}$} \\
\hline Article Info & \\
\hline $\begin{array}{l}\text { Accepted: } \\
\text { 07 September } 2017 \\
\text { Available Online: } \\
10 \text { October } 2017\end{array}$ & \\
\hline
\end{tabular}

\section{Introduction}

Sunflower oil is considered as premium when compared to other vegetable oils and is the largest selling oil in the branded oil segment. The crop requires a cool climate during germination and seedling growth. It requires warm weather from the seedling to flowering stage and sunny days during flowering to maturity. Sunflower can be grown on a wide range of soils and tolerates a moderate $\mathrm{pH}$ range and some salinity. It thrives best on deep loam soils with good drainage and irrigation facilities. Plant spacing is a major production factor that is often manipulated in order to ensure adequate plant population and to reduce yield losses due to overcrowding in arable crops. The choice of appropriate plant population also depends on the cost of planting methods, especially for hybrid seeds, because high quality seeds constitute a major prerequisite for successful production of oilseed crops.

In the central zone of Punjab, sunflower is grown in different crop rotations like, Paddypotato-sunflower, Paddy-peas-sunflower, Maize-potato-sunflower, Maize-toriasunflower etc. A number of farmers also grow the crop as flora for their bee keeping units. Sunflower requires a well pulverized and weed free land with adequate moisture supply. The land is prepared by doing two to three ploughing followed by planking. For sowing of seed a number of practices are followed by farmers; manual (dibbling), semimanual (use of marker followed by manual sowing) and mechanical (with locally 
manufactured planter). Due to short window period available between the harvest of potato crop and sowing of sunflower crop, many farmers prefer to sow the crop with available crop planter. According to farmers' point of view, sowing of sunflower seed with multiple crop planter helps in:

Ease in intercultural operations and timely operation

Cost and energy saving

Less labour requirement

Reduced drudgery

Efficient water use

Business opportunity as service provider through custom hiring

Improved productivity and profitability

This study was undertaken with the objective to evaluate the performance of sunflower sown by different methods in comparison to the manual sowing through systematic laboratory and field tests. The evaluation also focussed on yield attributing factors i.e. plant population, plant spacing, seed yield and economics of various sowing methods followed at the farmers' field.

\section{Materials and Methods}

The study was carried out at farmers' field at three locations with GPS coordinates of $075^{\circ} 17.134^{\prime} \mathrm{E} \& 31^{\circ} 06.413^{\prime} \mathrm{N}$; $075^{\circ} 18.024^{\prime} \mathrm{E}$ $\& \quad 31^{\circ} 07.142^{\prime} \mathrm{N}$ and $075^{\circ} 13.248^{\prime} \mathrm{E} \quad \&$ $31^{\circ} 12.848^{\prime} \mathrm{N}$ in Kapurthala and Jandhar districts in central zone of Punjab.

Sunflower seed was sown in the first week of February with $5 \mathrm{~kg}$ seed/ha after seed treatment with thiram @ $2 \mathrm{~g} / \mathrm{kg}$ seed.
Sowing of Pioneer's sunflower hybrid 64A57 was done by four methods i.e. Manually by dibbling method at $60 \times 30 \mathrm{~cm}$ apart $\left(\mathrm{T}_{1}\right)$, with the use of tractor operated marker to make a hole for seed placement and manual pouring of seed at $60 \times 30 \mathrm{~cm}\left(\mathrm{~T}_{2}\right)$, sowing with planter at $60 \times 20 \mathrm{~cm}$ apart $\left(\mathrm{T}_{3}\right)$ without thinning and $\left(\mathrm{T}_{4}\right)$ sowing with planter at $60 \mathrm{x}$ $20 \mathrm{~cm}$ apart followed by thinning manually after 20-25 DAS in order to maintain one plant per hill.

A complete package of practices recommended by the Punjab Agricultural University, Ludhiana was followed to raise a healthy crop. Various yield attributing factors namely plant population density, plant height and stem girth were determined at farmers' field as per recommended procedures.

Different parameters of flower i.e. head diameter, number of grains per head, 100 grains weight and grain weight per head were calculated to compare the performance of different methods. For this purpose, 50 plants were selected randomly for each parameter and the values were averaged. Cost of each and every operation was calculated for comparative study of different sowing methods. The cost of cultivation included cost of all the operations stating from land preparation till the harvest of crop. It includes cost of land preparation, seed cost, fertilizers, sowing cost, weeding, thinning, pesticides, harvesting and threshing of crop. The data thus obtained were statistically analysed using OPSTAT (Sheoran et al., 1998).

\section{Results and Discussion}

Effect of method of sowing on plant population

The data regarding plant population density $/ \mathrm{m}^{2}$ of crop sown with planter $\left(\mathrm{T}_{3}\right)$ recorded significantly higher values (10.67) 
than those sown with manual $\left(\mathrm{T}_{1}, 7.33\right)$ and semi manual methods $\left(\mathrm{T}_{2}, 8.67\right)$. The difference was found to be non-significant between $T_{1}$ and $T_{4}$ because manual thinning was performed in order to maintain a proper plant spacing, however, significantly higher number of plants $/ \mathrm{m}^{2}$ were observed in treatment $T_{2}$ than $T_{1}$ and $T_{3}$ (Table 1).

\section{Effect of method of sowing on plant height and stem girth}

It was observed that method of sowing did not affect plant height and stem girth significantly (Table 1) but a large variation in plant height was observed under treatment $\mathrm{T}_{3}$ (crop sown with planter without thinning). The values regarding stem girth showed that there was no particular trend associated either with plant height or methods of sowing.

\section{Effect on flower parameters and seed yield}

The flower is the basic yield attributing component in sunflower crop because on one plant only one flower is produced and that's why optimum plant population is very much essential for harvesting a good yield. Head diameter, head weight, average grain weight/head, 100 grain weight and average number of grains per flower were calculated for randomly selected flowers from each plot to determine the significance of planting methods on these factors.

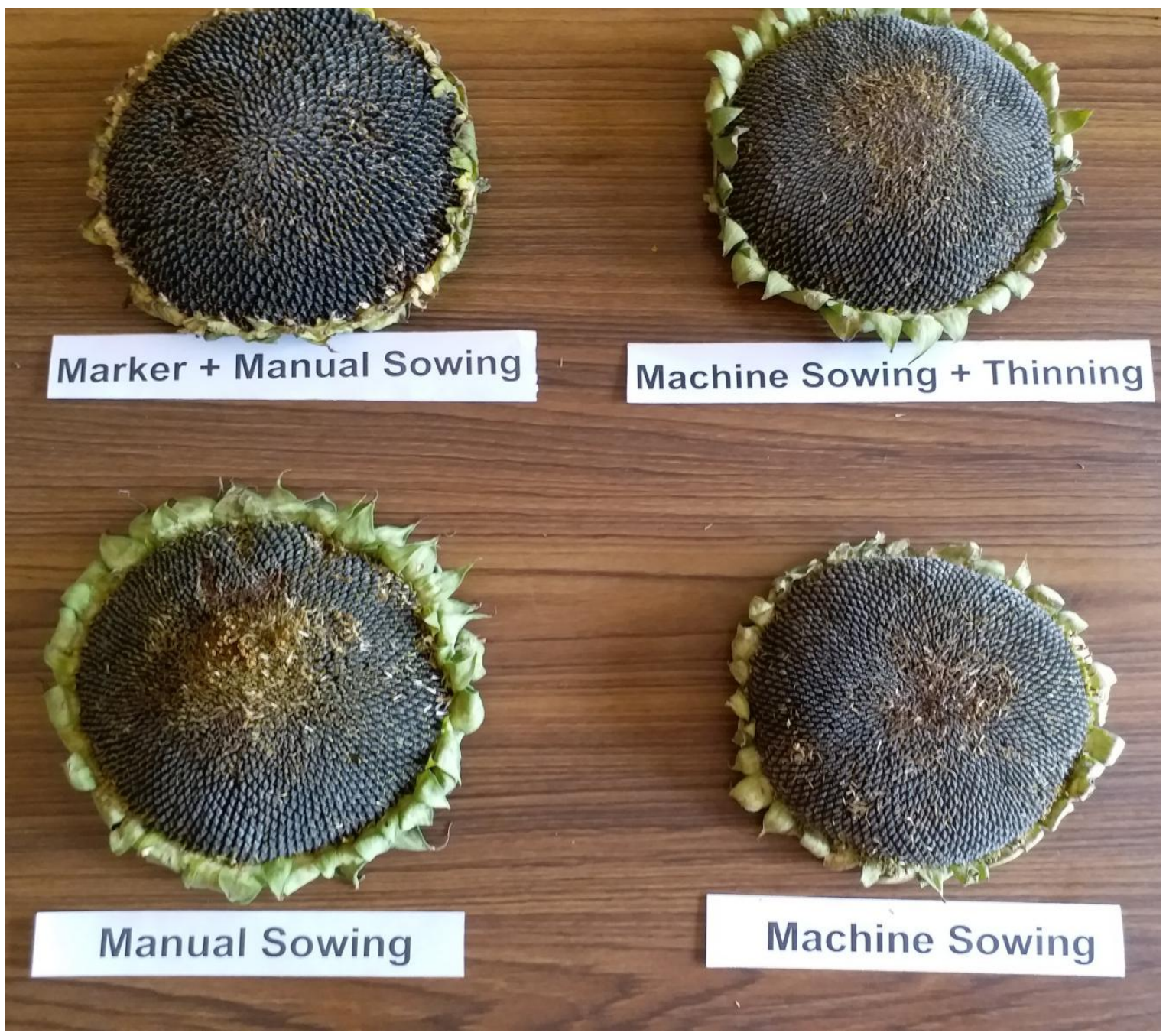


Int.J.Curr.Microbiol.App.Sci (2017) 6(10): 691-697

Table.1 Effect of sowing methods on growth, yield parameters and yield of sunflower

\begin{tabular}{|c|c|c|c|c|c|c|c|c|c|}
\hline Treatment & $\begin{array}{l}\text { No. of } \\
\text { plants/sq m }\end{array}$ & $\begin{array}{l}\text { Plant } \\
\text { height }(\mathrm{cm})\end{array}$ & $\begin{array}{l}\text { Stem girth } \\
(\mathrm{cm})\end{array}$ & $\begin{array}{l}\text { Head Diameter } \\
(\mathrm{cm})\end{array}$ & $\begin{array}{l}\text { Head } \\
\text { wt.(g) }\end{array}$ & $\begin{array}{l}\text { Average grain } \\
\text { wt/head (g) }\end{array}$ & $\begin{array}{l}100 \text { grain } \\
\text { wt (g) }\end{array}$ & $\begin{array}{l}\text { No. of } \\
\text { grains/head }\end{array}$ & $\begin{array}{l}\text { Yield } \\
\text { (q/ha) }\end{array}$ \\
\hline $\mathrm{T}_{1}$ & 7.33 & 164.33 & 5.63 & 14.43 & 168.31 & 87.84 & 2.09 & 1567.67 & 18.93 \\
\hline $\mathrm{T}_{2}$ & 8.67 & 163.33 & 5.93 & 16.17 & 173.16 & 91.89 & 2.57 & 1627.33 & 20.13 \\
\hline $\mathrm{T}_{3}$ & 10.67 & 156.67 & 5.43 & 13.43 & 125.44 & 85.34 & 1.98 & 1508.33 & 17.70 \\
\hline $\mathrm{T}_{4}$ & 7.33 & 163.33 & 5.73 & 15.30 & 170.30 & 90.09 & 2.17 & 1598.67 & 19.60 \\
\hline $\begin{array}{l}\text { C D } \\
(P=0.05)\end{array}$ & 1.22 & N/A & N/A & 0.63 & 3.19 & 1.08 & N/A & 30.53 & 0.46 \\
\hline
\end{tabular}


Table.2 Cost of cultivation under different methods of sowing

\begin{tabular}{|l|l|c|c|c|c|}
\hline Sr. & \multirow{2}{*}{ Field operation } & \multicolumn{4}{|c|}{ Cost of cultivation (Rs/ha) } \\
\cline { 3 - 6 } & & $\mathbf{T}_{\mathbf{1}}$ & $\mathbf{T}_{\mathbf{2}}$ & $\mathbf{T}_{\mathbf{3}}$ & $\mathbf{T}_{\mathbf{4}}$ \\
\hline 1 & Land preparation & 3000 & 3000 & 3000 & 3000 \\
\hline 2 & Cost of seed & 1500 & 1500 & 1500 & 1500 \\
\hline 3 & Fertilizers & 940 & 940 & 940 & 940 \\
\hline 4 & Sowing cost & & & & \\
& I)Labour Charges & 3500 & 4200 & - & - \\
& II)Machine rent & - & 750 & 1000 & 1000 \\
& III)Fuel consumption & - & 750 & 750 & 750 \\
\hline 5 & Weeding and earthing up & 2500 & 2500 & 2500 & 2500 \\
\hline 6 & Thinning & 2000 & - & 0 & 2000 \\
\hline 7 & Labour for irrigation & 2000 & 2000 & 2000 & 2000 \\
\hline 8 & Pesticides & 2500 & 2500 & 2500 & 2500 \\
\hline 9 & Harvesting+ Threshing & 7000 & 7000 & 7000 & 7000 \\
\hline & Total & $\mathbf{2 4 9 4 0}$ & $\mathbf{2 5 1 4 0}$ & $\mathbf{2 1 1 9 0}$ & $\mathbf{2 3 1 9 0}$ \\
\hline
\end{tabular}

Table.3 Profitability of sunflower crop under different treatments

\begin{tabular}{|l|c|c|c|c|c|}
\hline Treatment & $\begin{array}{c}\text { Yield } \\
\text { (q/ha) }\end{array}$ & $\begin{array}{c}\text { Selling rate } \\
\text { (Rs./q) }\end{array}$ & $\begin{array}{c}\text { Gross income } \\
\text { (Rs./ha) }\end{array}$ & $\begin{array}{c}\text { Gross cost } \\
\text { (Rs./ha) }\end{array}$ & $\begin{array}{c}\text { Gross profit } \\
\text { (Rs./ha) }\end{array}$ \\
\hline $\mathbf{T}_{\mathbf{1}}$ & 18.93 & 2800 & 53013 & 24940 & 28073 \\
\hline $\mathbf{T}_{\mathbf{2}}$ & 20.13 & 2800 & 56373 & 25140 & 31233 \\
\hline $\mathbf{T}_{\mathbf{3}}$ & 17.70 & 2800 & 49560 & 21190 & 28370 \\
\hline $\mathbf{T}_{\mathbf{4}}$ & 19.60 & 2800 & 54880 & 23190 & 31690 \\
\hline C.D. & $\mathbf{0 . 4 6}$ & - & $\mathbf{1 3 0 0}$ & - & $\mathbf{1 3 0 0}$ \\
\hline
\end{tabular}

It was observed that method of sowing has a significant effect on these parameters. The flowers under treatment $T_{2}$ (marker+ manual sown crop) recorded significantly higher values for various parameters compared to other methods of sowing. The flower diameter and weight were highest for these flowers and therefore, all other corresponding yield contributing factors like average grain weight/head, 100 grain weight and average number of grains per flower were found to be highest (Table 1). Further, the seed yield obtained in treatments $\mathrm{T}_{1}, \mathrm{~T}_{2}, \mathrm{~T}_{3}$ and $\mathrm{T}_{4}$ was found to be 18.93, 20.13, 17.70 and 19.60 $\mathrm{q} / \mathrm{ha}$, respectively and significantly highest yield was obtained in treatment $T_{2}$ in which seeds were sown with the help of marker and dibbling method. It was noticed that significantly lowest seed yield (17.70q/ha) was under treatment $T_{3}$ in which the plant population was significantly higher compared to all other three treatments. This might be due to the fact that plants grown at lower population reduce the overall competition between flower plants and thus, afforded them more efficient utilization of available resources to grow well and to increase yield attributes of sunflower plants (Radwan et al., 1996). The results obtained were in agreement with Olowe (2005) and Suzer (2010).

Mc Master et al., (2012) stated that final yield for sunflower crop is the sum result of individual plant emerging, developing, growing and ultimately producing a head. However, yield increases with increase plant 
density up to a level which defines the optimum plant population but further increasing of plant density can lead to a constant and even decreased yield (Viorel et al., 2015).

\section{Comparative cost of production under different methods of sowing}

The results revealed that minimum cost was involved in the machine sowing with planter whereas, maximum cost was involved in manual sowing (either with or without marker), in treatment $\mathrm{T}_{4}$, additional cost was involved in thinning operation carried out after 20-25 DAS as compared to $\mathrm{T}_{3}$ (Table 2). Except difference in the labour charges incurred in different treatments, all other costs remained same. These results were observed in agreement to El-Awad (2003), while evaluating the mechanical sowing of various field crops of cotton, sorghum and sunflower in comparison with manual sowing.

It was observed that maximum gross profit was obtained under treatment $\mathrm{T}_{4}$, in which crop was sown with planter and thinning was done manually after 20-25 DAS, however, timely availability of labour is must for carrying out thinning operation (Table 3). On the other hand, treatment $\mathrm{T}_{2}$, where seed was sown with the help of marker, incurred marginally less gross profit than $\mathrm{T}_{4}$, which was more suitable than $T_{4}$ due to requirement of labour at the sowing time itself. In treatment $\mathrm{T}_{3}$, where crop was sown with the help of planter and no thinning was performed, minimum yield was obtained and thus minimum gross profit. Hence, farmers were advised to go for sunflower sowing manually with the help of marker in order to increase the margin of profit from sunflower crop.

Sunflower crop was grown mainly after potato harvesting in comparison to spring maize/summermoong/muskmelon/water melon To boost up the economics of above given crop sequence, sunflower productivity needs to be increased by maintaining proper plant population. There is a recommendation of sowing of sunflower seed at $60 \times 30 \mathrm{~cm}$ but availability of labour is becoming a major constraint in central plain zone of Punjab. Therefore, the farmers in the area tried different methods of sowing at their own level including seed planter and seed marker. Krishi Vigyan Kendra, Kapurthala evaluated different methods of sowing at the farmer's field and concluded that it was economical to sow the crop manually with the help of marker fixed in the tractor, whereas, the crop sown with planter without thinning operation yielded significantly less as compared to other methods of sowing.

\section{References}

El-Awad, S.A., 2003. Farm evaluation of mechanical sowing of various field crops in irrigated Schemes. A paper submitted to the Crop Husbandry Committee. Agricultural Engineering Research Program, Agricultural Research Corporation, Wad Medani Sudan.

Mc Master, G.S., Buchleiter G W and Bausch W C 2012. Relationships between sunflower plant spacing and yield: importance of uniformity in spacing. Crop Sci, 52(1): 309-319

Olowe, V.I.O., 2005. Effect of plant population density on growth and yield of sunflower (Helianthus annuus L.) in the transition zone of south west Nigeria. Trop Agric Res \& Ext, 8:37-44

Radwan, F.I., 1996. Effect of mycorrhizae inoculation, phosphorus and potassium fertilization on growth, yield and its components of sunflower plants. J Agric Res Tanta Univ, 22(3): 357-375

Sheoran, O.P., Tonk D S, Kaushik L S, Hasija 
R C and Pannu R S 1998. Statistical Software Package for Agricultural Research Workers. Recent Advances in information theory, Statistics and Computer Applications by D.S. Hooda \& R.C. Hasija Department of Mathematics Statistics, CCSHAU, Hisar: 139-143.

Suzer, S., 2010. Effects of nitrogen and plant density on dwarf sunflower hybrids. Helia, 33(53):207-214

Viorel, I., Georgeta D, Adrian Gheorghe B, Marin D, Georgeta T, Lenutaluliana E and Daniel S 2015. Sunflower yield and yield components under different sowing conditions. Agric and Agril Sci Procedia, 6:44-51

\section{How to cite this article:}

Bindu, Manoj Sharma, Jatinder Manan and Gurmeet Singh. 2017. Evaluation of Different Methods of Sowing of Sunflower at Farmers' Field in Central Plain Zone of Punjab, India. Int.J.Curr.Microbiol.App.Sci. 6(10): 691-697. doi: https://doi.org/10.20546/ijcmas.2017.610.085 